BENTHM OPEN
CrossMark
Content list available at: www.benthamopen.com/TODENTJ/
DOI: $10.2174 / 1874210601812011070,2018,12,1070-1078$

RESEARCH ARTICLE

\title{
BAX Gene Overexpression in the Tongue Could Warn of Infection Risk due to Periodontal Pathogens
}

Germano Orrù ${ }^{1, *}$, Francesca Muggironi ${ }^{1}$, Antonello Mameli ${ }^{1,2}$, Cristina Demontis ${ }^{1,2}$, Bastiana Arcadu $^{1}$, Alessandra Scano ${ }^{1}$, Gloria Denotti ${ }^{2}$, Vincenzo Piras ${ }^{2}$, Carolina Girometta ${ }^{3}$, Blerina Zeza ${ }^{4}$ and Andrea Pilloni ${ }^{4}$

${ }^{I}$ Department of Surgical Sciences, Oral Biotechnology Laboratory (OBL), University of Cagliari, Cagliari, Italy

${ }^{2}$ Department of Surgical Sciences, School of Dentistry, University of Cagliari, Cagliari, Italy

${ }^{3}$ Department of Biology and Biotechnology "L. Spallanzani", University of Pavia, Pavia, Italy

${ }^{4}$ Department of Dentistry and Maxillofacial Surgery, Section of Periodontics, Sapienza University of Rome, Rome, Italy

Received: August 22, 2018

Revised: October 22, 2018

Accepted: November 19, 2018

\section{Abstract:}

Background:

Different host proteins play a central role in cell response during bacterial infections, the Bcl-2-Associated X protein (BAX) and Vascular Cell Adhesion Protein 1 (VCAM-1) are often reported in infective primary events during cell injury.

\section{Objective:}

The aim of this study is to evaluate the predictive value of these two proteins as biomarkers of oral bacterial infection, with particular emphasis on the tongue, which plays an important role in microbial homeostasis in the mouth.

\section{Methods:}

Twenty-nine patients were recruited and divided according to the Periodontal Index (CPI), 4 of them were severely compromised periodontal patients. Oral hygiene, gingival tissues and plaque presence were evaluated clinically. The laboratory analysis carried out on tongue tissue included: total bacterial genomes, proportion of specific periopathogens and BAX -VCAM-1 expression rate, while Reactive Oxygen Species (ROS) were measured in saliva.

\section{Results:}

Neither tongue microbiological status nor salivary ROS level corresponded with the state of disease. VCAM-1 mRNA expression rate was comparable in all patients but, on the contrary, BAX expression resulted high in periodontally-compromised patients and appears related to periodontal status in the analyzed subjects.

\section{Conclusion:}

This preliminary work suggests that the BAX protein is a possible candidate in a prognostic marker study for oral diseases started by periodontal bacteria. For example, none of the evaluated clinical and microbiological parameters could predict the presence, prognosis or recurrence of periodontal diseases. This biomarker could be a valuable tool in determining the risk, diagnosis and prognosis of this human illness.

Keywords: VCAM-1 and BAX proteins, Tongue biofilm, Periodontitis and incipient diagnosis, Periodontal pathogens, Reactive Oxygen Species (ROS), Microbial homeostasis.

\footnotetext{
* Address correspondence to this author at the Department of Surgical Sciences, Oral Biotechnology Laboratory (OBL), University of Cagliari, Via Ospedale 54, 09121 Cagliari, Italy; Tel: +39 070 537413; Fax: +39 070 537437; E-mail: orru@unica.it
} 


\section{INTRODUCTION}

Oral biofilm-related diseases are among the most common bacterial diseases in human beings [1 - 3]. In fact, periodontal disease, gingival bleeding and tongue infection (in patients with halitosis) are highly prevalent among adult populations worldwide [2, 4]. Furthermore, these bacteria are responsible for common local symptoms such as bad breath [5] and can be involved in important systemic diseases, such as atherosclerosis and cardiovascular deficiency [6].

Periodontal pathogens are normally located on the dorsum of the tongue and then on the sides of the teeth in the periodontal pockets of periodontal patients. In fact, the dorsum of the tongue and periodontal pocket biofilms share a related and similar microbial composition, for example in anaerobic Gram negative species [7 - 9] and therefore a spread of tongue- periodontium bacteria, via saliva, could be possible in the same subject $[10,11]$.

To date, the diagnosis of periodontal diseases (including halitosis) has been concentrated on clinical and microbiological analyses mainly on the bacterial side of the disease. Recently the principal periopathogens have been identified with high levels of specificity be means of Polymerase Chain Reaction (PCR) base procedures [12]. However, these methods are unable to determine preclinical stages, sufficient disease prognostic indexes, or recurrence/risk factors. In this context, host cell response showed a most important role during the infective process [13] and in this perspective, different authors have suggested that some proteins involved in apoptosis and in adhesive processes may be an important initial event in the microbial pathogenesis [14, 15].

VCAM-1 is a cellular membrane protein that mediates the adhesion of leucocytes to endothelial cells. This sialoglicoprotein is expressed in incipient lesions [16]. Weglarz et al. reported an increased expression of VCAM-1 induced by the lipopolisaccharides of Desulfuvibrio desulfuricans (a rod-shaped, anaerobic, gram-negative bacterium) but no other studies have been conducted on the role of this protein on oral bacterial diseases [17]. On the other hand, BAX (Bcl-2-Associated $\mathrm{X}$ protein) is known to induce cellular apoptosis. In vitro studies have demonstrated that Pseudomonas aeruginosa, Chlamydia spp., Helicobacter pylori and Mycobacterium tuberculosis induced a hyperexpression of BAX, hypothesizing that the apoptosis served as a defense mechanism against these bacteria [18, 19]. Insufficient evidence can be found regarding the role of BAX in oral inflammation. Based on this evidence, other authors have hypothesized that oral pathogens could also induce apoptotic stimulation, for example, during the shift from commensal to pathogen in tongue biofilm microbiota. Consequently, they could increase the expression of these proteins, which in turn could function as incipient inflammation diagnostic parameters.

The aim of the present study is to evaluate the levels of VCAM-1 and BAX protein production of epithelial cells from the dorsum of the tongue in the presence of oral pathogens and to investigate the possibility of using these markers for the detection of early stages of oral diseases.

\section{MATERIALS AND METHODS}

\subsection{Patient Selection}

Twenty-nine (29) subjects from the Clinical and University Dental Department of Cagliari, Italy were recruited based on the following inclusion criteria:

- No systemic diseases;

- Presence of at least 20 teeth (minimum 5 teeth per quadrant);

- No oral lesions;

- No removable prostheses;

- No history of pharmacotherapy which could influence the outcome of the study;

- No use of medications in the 6 months prior to treatment.

For each subject, the assessment of the oral status was performed by means of these clinical parameters:

i. Oral hygiene (poor, moderate, good, excellent);

ii. Gingival tissues evaluated by means of a 2-score scale (0-pink gingival tissues, 1-red edematous gingiva);

iii. Periodontal status evaluated using a 4-score scale described by Ainamo et al, as CPI score, briefly: $0=$ Healthy, 1 = Bleeding, 2 = Calculus and bleeding, 3 = Shallow periodontal pocket $4-5 \mathrm{~mm}, 4=$ Deep periodontal pocket $6 \mathrm{~mm}$ or more [20]. 
Patients were divided into four groups:

$\checkmark 7$ Periodontally healthy patients, CPI $=0$.

3 Subjects bleeding after probing, CPI $=1$

15 Moderate inflammatory state, CPI $=2$

4 Periodontally compromised, CPI $=3-4$.

\subsection{Sample Collection}

Tongue biofilm and saliva samples were collected from male and female subjects ( 7 to 61 years old), recruited from the Department of Dental Disease Prevention (AOU Cagliari).

For each patient, approval was obtained, and informed consent was given by patients for the collection of biological samples. The study was approved by the Independent Ethic Committee (Prot. PG/2017/16799).

Informed consent was signed prior to study initiation. All patients were instructed to rinse with sterile water 10 minutes prior to sample collection; then, to spit saliva directly into a $50 \mathrm{ml}$ "Falcon" model tube (Thermo Fisher Scientific, Carlsbad, CA, USA) for the evaluation of the oxidative stress of the oral cavity cells. Afterward, two groups of samples were taken from the tongue dorsum using a single-use minibrush. Sample collection from this site was performed based on the evidence that the dorsum of the tongue serves as a reservoir for periopathogens [21]. One brush was placed in $70 \mu \mathrm{l}$ of DMSO (Dimethylsulfoxide, Carlo Erba, Milano, Italy) and further utilized for the detection of periopathogens. The other brush was placed in $500 \mu$ l of TRIzol ${ }^{\circledR}$ (Invitrogen, Thermo Fischer, Carlsbad, CA, USA) for the extraction of human RNA and further analyses of gene expression. The former specimen was analyzed with quantitative and qualitative PCR- based methods to determine the total bacterial count and the proportion of specific periopathogens: Aggregatibacter actinomycetemcomitans, Prevotella intermedia, Porphyromonas gingivalis, Tannerella forsythia, and the latter for the expression of VCAM-1 and BAX genes.

\subsection{Molecular Analysis}

As previously described, molecular analysis was focused on the detection of:

1. The salivary antioxidant concentration;

2. VCAM-1 and BAX expression levels of tongue cells;

3. The periodontal pathogen profile of the tongue biofilm.

The antioxidant level in saliva was measured by a spectrophotometric procedure with Sat Test, (mf ODONTOVIS Farmantis, Parma, Italy) following the manufacturer's instructions. Saliva antioxidant status was expressed as $\mathrm{mEq} / \mathrm{L}$ of vitamin C [22]. BAX -VCAM-1 gene expression was performed by RT-real time PCR. All PCR primers for quantification of VCAM-1/BAX expression were designed on the GenBank sequences: NM 004324, for BAX; NM 080682 for VCAM-1 gene and NM 001101 for reference housekeeping gene (Beta-actin). The primer sequences were 5'-3':

- BAX: F-GCTTCAGGGTTTCATC; R-CCTTGAGCACCAGTTT;

- VCAM-1: F-ACCACCCCAGAATCTA; R-GAGGGCCACTCAAAT;

- Beta actin: F-GCATGgGTCAGAAGG, R-AGgCGTACAGGGATAG.

Where: $\mathrm{F}=$ forward oligos and $\mathrm{F}=$ reverse

These primer pairs spanning 293 to 297 bp segments were designed by standard procedures described in the literature [12]. All primer pairs were checked for their efficiency on serial dilutions of cDNA. Quantitative RT PCR was essentially as previously described [23]. Retro-transcription was carried out by using the ImProm-II Reverse Transcriptase Kit (Promega, Fitchburg, WI, USA). Quantitative real time PCR was performed in a Light Cycler apparatus (Roche, Basel, Switzerland) by using the Light Cycler DNA-Master SYBR Green I Kit (Roche, Basel, Switzerland). Relative gene expression was analysed by using the $2^{-\Delta \Delta \mathrm{CT}}$ method $[24$ - 26]. Molecular microbiological analysis for the periodontal pathogens of the tongue by conventional PCR was performed with the method described by Orrù et al. [12], and using $1 \mu \mathrm{l}$ of DMSO suspension. All RNA samples were measured with the quantitative method (Qubit ${ }^{\circledR}$ RNA HS Assay Kit, Lifetechnologies, Carlsbad, CA, USA) according to the manufacturer's instructions. 


\subsection{Statistical Analysis}

The absolute quantification of total bacteria with real time PCR was performed by Escherichia coli standard curve following a previously published protocol [27]; linear correlation $\mathrm{R}^{2}$ ranged from 0.97 to 0.99 . For each analysis, three distinct biological replicas were made and quantitative data were expressed as mean \pm SD. Values of changes in gene expression above 2 or below 0.5 were considered significant.

\section{RESULTS}

\subsection{Comparison of Tongue Biofilm Amount with Antioxidant Response in Saliva}

The total bacterial count was evaluated in healthy and periodontally-compromised patients. Absolute quantification revealed that the total bacterial count varied significantly between the analyzed subjects, from $5 \times 10^{4}$ to $3.4 \times 10^{8}$ bacterial genomes $/ \mu 1$ DNA extract (Fig. 1).

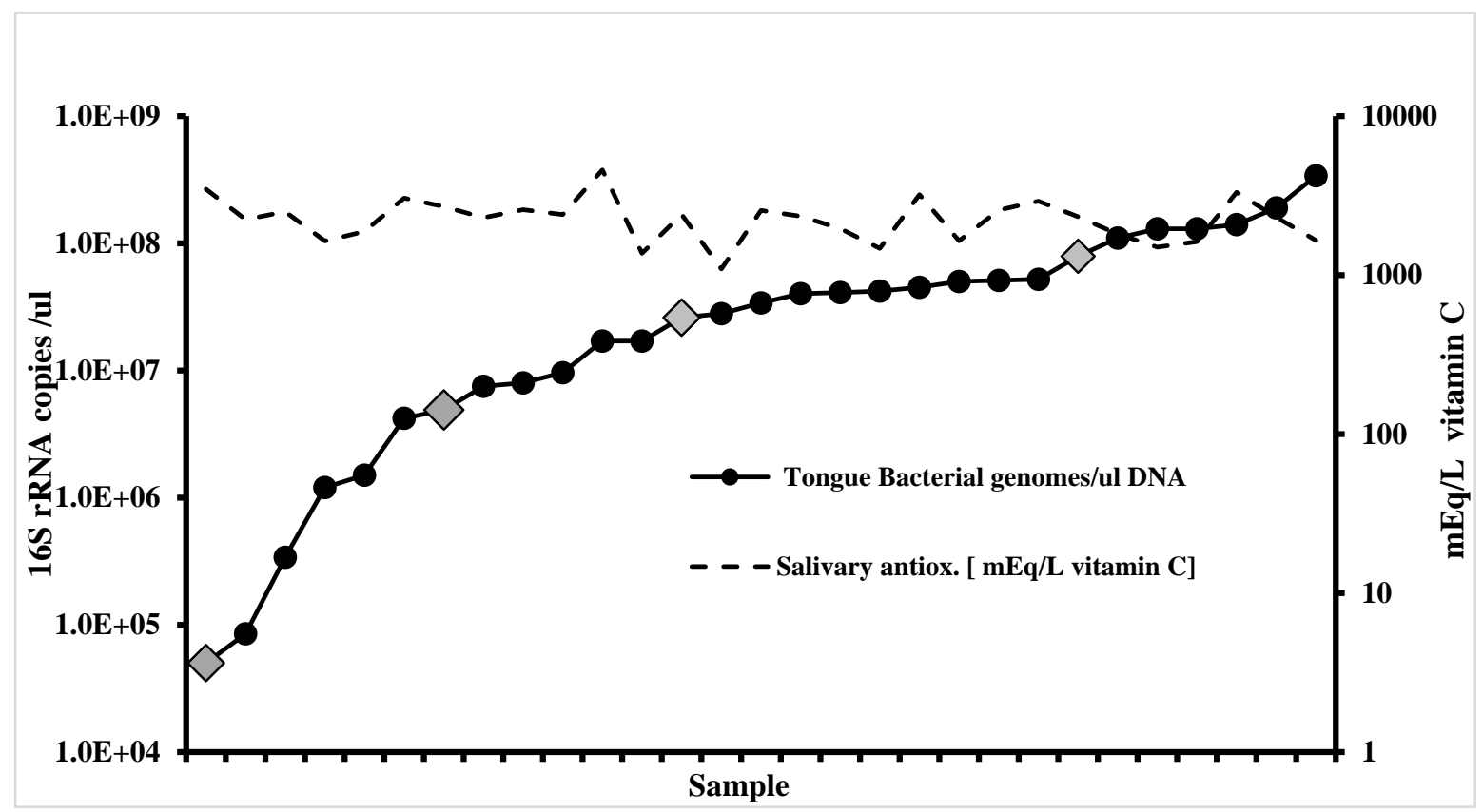

Fig. (1). Antioxidant levels in saliva, in 29 subjects sorted by tongue bacteria amount. The rhomboidal dots represent the periodontally-compromised patients (CPI score $\geq 3$ ).

The results suggested that tongue biofilm amount or periodontal condition did not show any correlation with salivary stress. In fact, the salivary oxidative stress was quite constant between healthy and periodontally- compromised subjects, although the latter presented a higher total bacterial count, $P>0.01$ (Fig. 1).

\subsection{Periopathogens, Periodontal Status and Oxidative Salivary Stress}

The greatest prevalence of periopathogens in these samples was found for Tannerella forsythia and Prevotella intermedia, (Table 1). One patient's tongue was shown to be infected with low Leukotoxic genotype 652 of Aggregatibacter actinomycetemcomitans. T. forsythia was the most prevalent periopathogen, present in $92 \%$ of the samples. These results are in accordance with a previous study on the frequency of periodontal bacteria found in Sardinian patients [12], even in healthy subjects, suggesting the possible existence of low pathogenicity clones. In accordance with Socransky's previous findings, P. intermedia was detected in $25 \%$ of patients, $20 \%$ and $57 \%$ in healthy and periodontally-compromised subjects, respectively (Table 1) $[23,28]$. The presence of these bacterial species in healthy subjects may suggest the existence of a commensal status of oral microbiota where this bacterial count has not reached the critical mass necessary to express pathogenicity, or following the absence of high pathogenicity clones. It was noticed that patients resulting positive for $P$. intermedia, were positive for $T$. forsythia as well. It was also observed that the periodontal condition was not related to either tongue periodontal bacteria profile, or to salivary stress. 
Table 1. Results of classic PCR according to patients' periodontal status.

\begin{tabular}{|c|c|c|c|c|c|c|c|}
\hline \multirow{3}{*}{$\begin{array}{c}\text { CPI } \\
- \\
4\end{array}$} & \multirow{3}{*}{$\begin{array}{c}\text { P.g. } \\
- \\
\text { Pos } \\
\end{array}$} & \multirow{3}{*}{$\begin{array}{c}\text { P.i. } \\
- \\
\text { Pos } \\
\end{array}$} & \multirow{3}{*}{$\begin{array}{c}\text { A.a. } \\
- \\
\end{array}$} & \multirow{3}{*}{$\begin{array}{c}\text { T.f. } \\
- \\
\text { Pos }\end{array}$} & \multicolumn{3}{|c|}{ mEq/L Vitamin C Saliva } \\
\hline & & & & & Value & \multirow{2}{*}{$\begin{array}{c}\text { Mean } \\
- \\
\end{array}$} & \multirow{2}{*}{$\begin{array}{c}\text { Median } \\
- \\
\end{array}$} \\
\hline & & & & & 1812 & & \\
\hline 3 & Pos & Pos & - & Pos & 3469 & - & - \\
\hline 3 & - & - & - & Pos & 2692 & 2266 & 2252 \\
\hline 3 & - & - & - & Pos & 1093 & - & - \\
\hline 2 & - & - & - & Pos & 2235 & - & - \\
\hline 2 & - & - & - & Pos & 1637 & - & - \\
\hline 2 & - & - & - & Pos & 2293 & - & - \\
\hline 2 & Pos & - & - & - & 2576 & - & - \\
\hline 2 & - & Pos & - & Pos & 4587 & - & - \\
\hline 2 & Pos & - & - & Pos & 1369 & - & - \\
\hline 2 & - & - & - & Pos & 2547 & - & - \\
\hline 2 & - & - & - & Pos & 2343 & - & - \\
\hline 2 & - & - & - & Pos & 1958 & 2358 & 2293 \\
\hline 2 & - & Pos & - & Pos & 1470 & - & - \\
\hline 2 & - & - & - & Pos & 3208 & - & - \\
\hline 2 & - & - & - & Pos & 2561 & - & - \\
\hline 2 & - & - & - & Pos & 1623 & - & - \\
\hline 2 & - & - & - & Pos & 3317 & - & - \\
\hline 2 & Pos & - & - & Pos & 1652 & - & - \\
\hline 1 & - & - & - & Pos & 2504 & - & - \\
\hline 1 & - & - & - & Pos & 2409 & 2409 & 2143 \\
\hline 1 & - & - & - & Pos & 1500 & - & - \\
\hline 0 & - & - & - & Pos & 1877 & - & - \\
\hline 0 & - & Pos & Pos & Pos & 3049 & - & - \\
\hline 0 & - & - & - & Pos & 2402 & - & - \\
\hline 0 & - & Pos & - & Pos & 1645 & 2323 & 2323 \\
\hline 0 & - & Pos & - & Pos & 2917 & - & - \\
\hline 0 & - & - & - & - & 2323 & - & - \\
\hline 0 & - & - & - & - & 2307 & - & - \\
\hline
\end{tabular}

Legend: P.g. (Prophyromonas gingivalis), P.i. (Prevotella intermedia), T.f. (Tannerella forsythia), A.a. (Aggregatibacter actinomycetemcomitans). Pos $=$ detectable DNA, $[>100$ copies $/$ ul $]$.

\subsection{Expression of VCAM-1 and BAX Genes}

Of the total 29 subjects recruited, four resulted as being periodontally-compromised. RT PCR analysis performed in RNA samples from tongue samples showed that VCAM-1 gene was not expressed in periodontal or in healthy subjects (data not shown), while a significant motif was detected with the real time PCR of BAX gene in these patients. Fig. (2) shows the list of patient rankings according to a different scale of periodontal index (CPI score) evaluated with BAX gene expression (fold of housekeeping gene B-actin). The results show an increase in media end median values in gene expression from healthy to periodontally- compromised patients. For example, the severely compromised periodontal patient (PZ 1, CPI = 4, Table 1), showed the greatest BAX expression value, 21 fold in comparison with housekeeping gene, while the control healthy patient (PZ 26) showed a BAX expression of 1. 


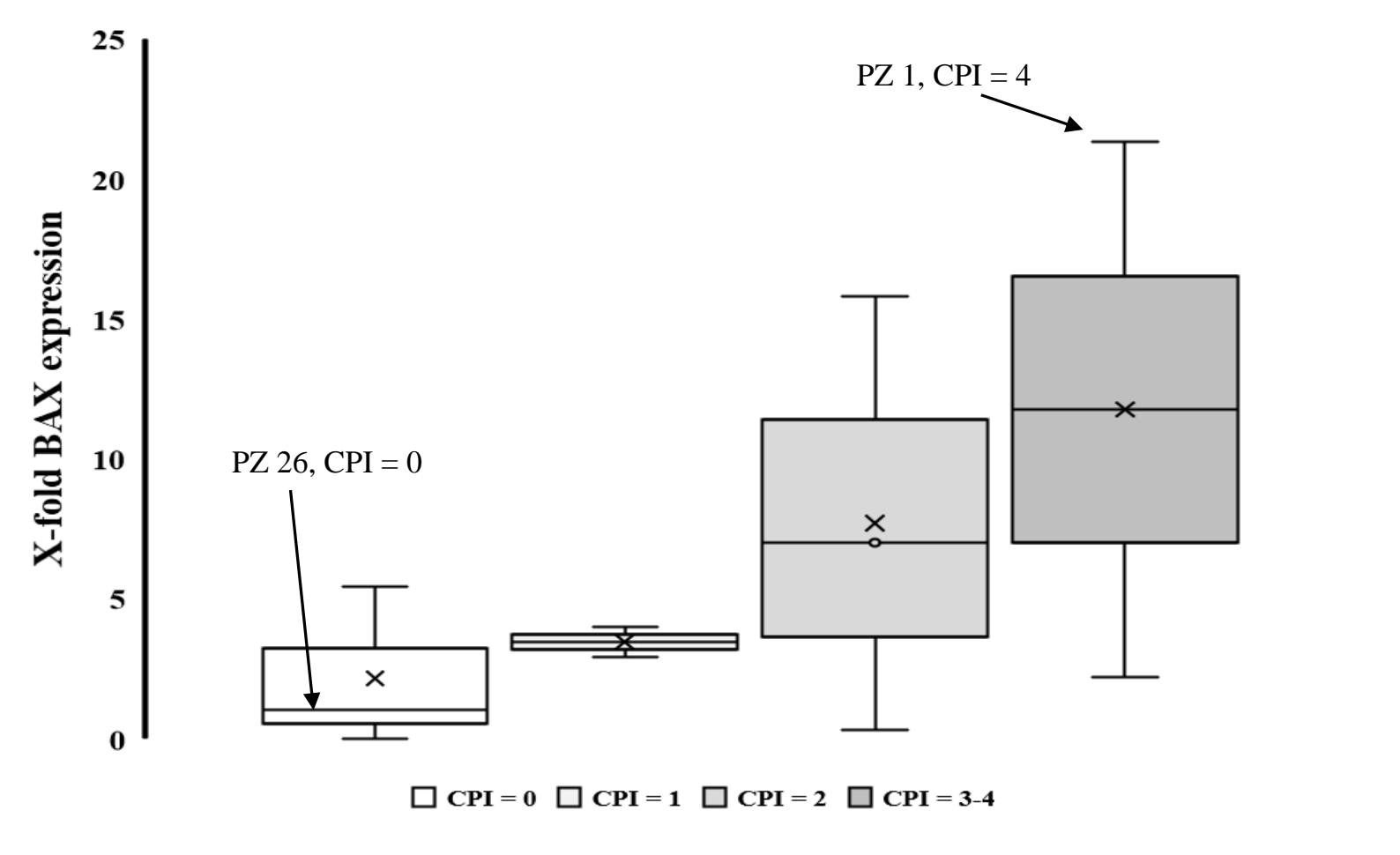

Fig. (2). BCL2 Associated X (BAX) gene expression pattern in 29 subjects ordered by periodontal status (CPI from 0 to 4 ). Horizontal line - represents the median, while $\mathrm{X}=$ media values for each group. The patient with the worst clinical parameters $(\mathrm{CPI}=$ 4) showed the highest BAX expression value.

\section{DISCUSSION}

The results obtained in this study are restricted to a limited number of patients followed as a cohort. Even though this was a limit, the present protocol could be used for subsequent studies investigating the possibility of using genetic expression as a biological marker for the prognosis of oral diseases caused by periodontal pathogens. It is a fact that up till now, even the most advanced microbiological diagnostic tool normally used for microbiological analysis, for example, PCR real time, is unable to identify the preclinical stages of periodontal diseases [23, 27 - 30] or to predict an incipient risk for this illness. This is determined by the fact that in biofilm related diseases: (1) the pathogenicity of a biofilm depends on a bacterial count of pathogens that overpasses the critical count/mass, (2) for pathogens that have the same critical count/mass, the virulence of the biofilm depends on clonal populations of different pathogens [31], and (3) there are different levels of individual susceptibility consequent to the interaction between genetic and behavioural factors [32 - 34]. The etiologic diagnosis of infection on the dorsum of the tongue is important not only for the risk that the related biofilm could present for possible periodontal infection, but also because some authors have suggested that the systemic dissemination of these pathogens, albeit accidental, i.e. tongue scraping, could become a risk factor for cardiovascular infections $[35,36]$. This study was based on the hypothesis that biochemical signals released from host cells during infection could have a prognostic function in the characterization of the tongue's pathogenic biofilm. Qualitative microbiological analyses for the detection of specific pathogens did not correspond to a presence of oral disease, as pathogens were also detected in healthy patients (albeit in smaller amounts), which is in accordance with previous studies $[37,38]$. The presence of these bacterial species in healthy subjects may suggest the existence of no pathogenic stages in the tongue biofilm, where the bacterial count or its pathogenic potentiality has not reached the critical mass necessary to express pathogenicity. For example, T. forsythia was the most prevalent periopathogen in this study, present in $92 \%$ of the samples from both healthy and diseased patients. This result is supported by previous studies on the frequency of periopathogens found in Sardinian patients, even in healthy subjects, suggesting the possible existence of low pathogenicity clones [12]. It was noticed that most patients resulting positive for $P$. intermedia, were positive for T. forsythia as well. It was also observed that tongue infection was not related to periodontal condition and oral hygiene. The same result was obtained from the quantification of salivary anti-oxidants. Of the two analysed genetic markers (VCAM-1, BAX), VCAM-1 was not present in the samples examined. It can be speculated that this protein is probably expressed in the incipient stages of bacterial colonization, which is a hypothesis that could be evaluated in the future in vitro and in vivo studies. On the other hand, BAX expression was greater in infected patients. 
The extended range of expression values of BAX in these patients may be related to the different critical mass of the high pathogenic periopathogens present in the respective tongue biofilms. This hypothesis may justify the distribution of tongue biofilm (bacteria/samples) in subjects ranked according to BAX gene expression. The results show that the regression of tongue biofilm and expression of BAX genes go in opposite directions. If this could also be confirmed even by other studies, it might suggest the protective role of non-pathogenic tongue biofilm on cell health. These results are in accordance with previous studies reporting the important physiological role of bacterial biofilm in modulating taste [39].

Two critical points are present in this study: the first is characterised by the low number of samples analysed, while a second limit, in our opinion, is the fact that the study was restricted to just one region (tongue) of the oral tissues. In fact, we have speculated on the need for further studies/experiments to investigate the probably interesting role of the Bcl-2 associate X protein as a biological indicator of pathogenic biofilm on the tongue and on other tissues, i.e. gum and periodontal region. In fact, as demonstrated by other microbiological studies, the presence of this protein is strictly related to host cell injury during bacterial infection, for example, as an apoptotic activator [40, 41]. In this context Bcl-2 could reveal the presence of an altered microbiota in the oral tissues, with a great presence of pathogenic anaerobes able to damage the epithelium of the tongue, as well as other oral tissues, such as, for example, the periodontal district.

\section{CONCLUSION}

Until now, proteomics and genomics have served as the major biological tools in comprehending periodontal disease. This work provides a further suggestion for some new approaches. In particular, the study of the oral tissues of mRNAs related to cell damage could be a valid tool for periodontal disease prediction and control.

\section{Links/Footnotes}

$\checkmark$ Human gene Database $(\mathrm{BAX})=$ https://www.genecards.org/cgi-bin/carddisp.pl?gene=BAX

BAX on wikigenes $=$ https://www.wikigenes.org/e/gene/e/581.html

\section{ETHICS APPROVAL AND CONSENT TO PARTICIPATE}

The study was approved by the Independent Ethic Committee (Prot. PG/2017/16799).

\section{HUMAN AND ANIMAL RIGHTS}

No animals were used in this research. All human research procedures followed were in accordance with the ethical standards of the committee responsible for human experimentation (institutional and national), and with the Helsinki Declaration of 1975, as revised in 2013.

\section{CONSENT FOR PUBLICATION}

Informed consent was given by patients for the collection of biological samples and signed prior to study initiation.

\section{CONFLICT OF INTEREST}

The authors declare no conflict of interest, financial or otherwise.

\section{ACKNOWLEDGEMENTS}

This work was supported by a "Regione Autonoma della Sardegna" Grant, FSE2007-2013 L.R. 7/2007 "Promozione della ricerca scientifica e dell'innovazione tecnologica in Sardegna".

\section{REFERENCES}

[1] Palmer RJ. Oral bacterial biofilms: History in progress. Microbiology 2009; 155(Pt 7): 2113-4. [http://dx.doi.org/10.1099/mic.0.030809-0] [PMID: 19460821]

[2] Filoche S, Wong L, Sissons CH. Oral biofilms: Emerging concepts in microbial ecology. J Dent Res 2010; 89(1): 8-18. [http://dx.doi.org/10.1177/0022034509351812] [PMID: 19918089]

[3] Flemmig TF, Beikler T. Control of oral biofilms. Periodontol 2000 2011; 55(1): 9-15. [http://dx.doi.org/10.1111/j.1600-0757.2010.00383.x] [PMID: 21134225]

[4] Nagy A, Brugoviczky Z, Novák P, Nagy G. Clinical importance and diagnosis of halitosis. Fogorv Sz 2012; 105(3): 105-11. [PMID: 23240492] 
[5] Aylikcı BU, Colak H. Halitosis: From diagnosis to management. J Nat Sci Biol Med 2013; 4(1): 14-23. [http://dx.doi.org/10.4103/0976-9668.107255] [PMID: 23633830]

[6] Dietrich T, Webb I, Stenhouse L, et al. Evidence summary: The relationship between oral and cardiovascular disease. Br Dent J 2017; 222(5): $381-5$. [http://dx.doi.org/10.1038/sj.bdj.2017.224] [PMID: 28281612]

[7] Mevio E, Perano D, Pagani L, Zanella C, Giacobone E, Cardillo A. The role of tissue colonization and bacterial resistance in recurrent tonsillitis. Acta Otolaryngol Suppl 1996; 523: 133-7. [PMID: 9082759]

[8] Offenbacher S, Barros SP, Singer RE, Moss K, Williams RC, Beck JD. Periodontal disease at the biofilm-gingival interface. J Periodontol 2007; 78(10): 1911-25.

[http://dx.doi.org/10.1902/jop.2007.060465] [PMID: 18062113]

[9] Saad S, Greenman J. Tongue biofilm areal density and tongue coating index. J Breath Res 2008; 2(1): 017008 [http://dx.doi.org/10.1088/1752-7155/2/1/017008] [PMID: 21386152]

[10] Awano S, Gohara K, Kurihara E, Ansai T, Takehara T. The relationship between the presence of periodontopathogenic bacteria in saliva and halitosis. Int Dent J 2002; 52(Suppl. 3): 212-6.

[http://dx.doi.org/10.1002/j.1875-595X.2002.tb00927.x] [PMID: 12090455]

[11] Calil C, Liberato FL, Pereira AC, de Castro Meneghim M, Goodson JM, Groppo FC. The relationship between volatile sulphur compounds, tongue coating and periodontal disease. Int J Dent Hyg 2009; 7(4): 251-5. [http://dx.doi.org/10.1111/j.1601-5037.2009.00366.x] [PMID: 19832911]

[12] Orrù G, Marini MF, Ciusa ML, et al. Usefulness of real time PCR for the differentiation and quantification of 652 and JP2 Actinobacillus actinomycetemcomitans genotypes in dental plaque and saliva. BMC Infect Dis 2006; 6: 98. [http://dx.doi.org/10.1186/1471-2334-6-98] [PMID: 16772039]

[13] Bodet C, Chandad F, Grenier D. Inflammatory responses of a macrophage/epithelial cell co-culture model to mono and mixed infections with Porphyromonas gingivalis, Treponema denticola, and Tannerella forsythia. Microbes Infect 2006; 8(1): 27-35. [http://dx.doi.org/10.1016/j.micinf.2005.05.015] [PMID: 16153871]

[14] Sharifi AM, Hoda FE, Noor AM. Studying the effect of LPS on cytotoxicity and apoptosis in PC12 neuronal cells: Role of Bax, Bcl-2, and Caspase-3 protein expression. Toxicol Mech Methods 2010; 20(6): 316-20. [http://dx.doi.org/10.3109/15376516.2010.486420] [PMID: 20521854]

[15] Roth GA, Moser B, Roth-Walter F, et al. Infection with a periodontal pathogen increases mononuclear cell adhesion to human aortic endothelial cells. Atherosclerosis 2007; 190(2): 271-81.

[http://dx.doi.org/10.1016/j.atherosclerosis.2006.03.018] [PMID: 16620832]

[16] O'Brien KD, McDonald TO, Chait A, Allen MD, Alpers CE. Neovascular expression of E-selectin, intercellular adhesion molecule-1, and vascular cell adhesion molecule-1 in human atherosclerosis and their relation to intimal leukocyte content. Circulation 1996; 93(4): 672-82. [http://dx.doi.org/10.1161/01.CIR.93.4.672] [PMID: 8640995]

[17] Weglarz L, Dzierzewicz Z, Skop B, et al. Desulfovibrio desulfuricans lipopolysaccharides induce endothelial cell IL-6 and IL-8 secretion and E-selectin and VCAM-1 expression. Cell Mol Biol Lett 2003; 8(4): 991-1003. [PMID: 14668922]

[18] Jungas T, Verbeke P, Darville T, Ojcius DM. Cell death, BAX activation, and HMGB1 release during infection with Chlamydia. Microbes Infect 2004; 6(13): 1145-55.

[http://dx.doi.org/10.1016/j.micinf.2004.07.004] [PMID: 15488733]

[19] Sly LM, Hingley-Wilson SM, Reiner NE, McMaster WR. Survival of Mycobacterium tuberculosis in host macrophages involves resistance to apoptosis dependent upon induction of antiapoptotic Bcl-2 family member Mcl-1. J Immunol 2003; 170(1): 430-7. [http://dx.doi.org/10.4049/jimmunol.170.1.430] [PMID: 12496428]

[20] Ainamo J, Barmes D, Beagrie G, Cutress T, Martin J, Sardo-Infirri J. Development of the World Health Organization (WHO) community periodontal index of treatment needs (CPITN). Int Dent J 1982; 32(3): 281-91. [PMID: 6958657]

[21] Maciorkowska E, Kaczmarski M, Panasiuk A, Kondej-Muszynska K, Kemonai A. Soluble adhesion molecules ICAM-1, VCAM-1, P-selectin in children with Helicobacter pylori infection. World J Gastroenterol 2005; 11(43): 6745-50. [http://dx.doi.org/10.3748/wjg.v11.i43.6745] [PMID: 16425378]

[22] Bakhtiari S, Bigom Taheri J, Bakhshi M, et al. Effect of vitamin C on salivary total antioxidant capacity in smokers. Iran J Pharm Res 2012; 11(4): 1045-9. [PMID: 24250535]

[23] Gibbons RJ, Socransky SS, Dearaujo WC, Vanhoute J. Studies of the Predominant Cultivable Microbiota of Dental Plaque. Arch Oral Biol 1964; 9: 365-70. [http://dx.doi.org/10.1016/0003-9969(64)90069-X] [PMID: 14170653]

[24] Faveri M, Feres M, Shibli JA, Hayacibara RF, Hayacibara MM, de Figueiredo LC. Microbiota of the dorsum of the tongue after plaque accumulation: An experimental study in humans. J Periodontol 2006; 77(9): 1539-46. 
[http://dx.doi.org/10.1902/jop.2006.050366] [PMID: 16945032]

[25] Denotti G, Piga R, Montaldo C, et al. In vitro evaluation of Enterococcus faecalis adhesion on various endodontic medicaments. Open Dent J 2009; 3: 120-4.

[http://dx.doi.org/10.2174/1874210600903010120] [PMID: 19557151]

[26] Livak KJ, Schmittgen TD. Analyses of relative gene expression data using real-time quantitative PCR and the 2 (-Delta Delta C(T)) Method. Methods 2001; 25(4): 402-8.

[http://dx.doi.org/10.1006/meth.2001.1262] [PMID: 11846609]

[27] Tanaka M, Yamamoto Y, Kuboniwa M, et al. Contribution of periodontal pathogens on tongue dorsa analyzed with real-time PCR to oral malodor. Microbes Infect 2004; 6(12): 1078-83. [http://dx.doi.org/10.1016/j.micinf.2004.05.021] [PMID: 15380777]

[28] Ximénez-Fyvie LA, Haffajee AD, Socransky SS. Comparison of the microbiota of supra- and subgingival plaque in health and periodontitis. J Clin Periodontol 2000; 27(9): 648-57.

[http://dx.doi.org/10.1034/j.1600-051x.2000.027009648.x] [PMID: 10983598]

[29] Starkenmann C, Le Calvé B, Niclass Y, Cayeux I, Beccucci S, Troccaz M. Olfactory perception of cysteine-S-conjugates from fruits and vegetables. J Agric Food Chem 2008; 56(20): 9575-80. [http://dx.doi.org/10.1021/jf801873h] [PMID: 18811169]

[30] Kawada M, Yoshida A, Suzuki N, et al. Prevalence of Porphyromonas gingivalis in relation to periodontal status assessed by real-time PCR. Oral Microbiol Immunol 2004; 19(5): 289-92. [http://dx.doi.org/10.1111/j.1399-302X.2004.00154.x] [PMID: 15327639]

[31] Boutaga K, van Winkelhoff AJ, Vandenbroucke-Grauls CM, Savelkoul PH. The additional value of real-time PCR in the quantitative detection of periodontal pathogens. J Clin Periodontol 2006; 33(6): 427-33. [http://dx.doi.org/10.1111/j.1600-051X.2006.00925.x] [PMID: 16677332]

[32] Hyvärinen K, Laitinen S, Paju S, et al. Detection and quantification of five major periodontal pathogens by single copy gene-based real-time PCR. Innate Immun 2009; 15(4): 195-204 [http://dx.doi.org/10.1177/1753425908101920] [PMID: 19586997]

[33] Jervøe-Storm PM, AlAhdab H, Koltzscher M, Fimmers R, Jepsen S. Quantification of periodontal pathogens by paper point sampling from the coronal and apical aspect of periodontal lesions by real-time PCR. Clin Oral Investig 2010; 14(5): 533-41. [http://dx.doi.org/10.1007/s00784-009-0333-x] [PMID: 19693550]

[34] Asikainen S, Chen C, Saarela M, Saxén L, Slots J. Clonal specificity of Actinobacillus actinomycetemcomitans in destructive periodontal disease. Clin Infect Dis 1997; 25(Suppl. 2): S227-9. [http://dx.doi.org/10.1086/516211] [PMID: 9310687]

[35] Baker PJ, Roopenian DC. Genetic susceptibility to chronic periodontal disease. Microbes Infect 2002; 4(11): $1157-67$. [http://dx.doi.org/10.1016/S1286-4579(02)01642-8] [PMID: 12361916]

[36] Trombelli L. Susceptibility to gingivitis: A way to predict periodontal disease? Oral Health Prev Dent 2004; 2(Suppl. 1): 265-9. [PMID: 15646584]

[37] Asikainen SE. Periodontal bacteria and cardiovascular problems. Future Microbiol 2009; 4(5): 495-8. [http://dx.doi.org/10.2217/fmb.09.21] [PMID: 19492958]

[38] Blaizot A, Vergnes JN, Nuwwareh S, Amar J, Sixou M. Periodontal diseases and cardiovascular events: Meta-analysis of observational studies. Int Dent J 2009; 59(4): 197-209. [PMID: 19774803]

[39] Redmond AM, Meiklejohn C, Kidd TJ, Horvath R, Coulter C. Endocarditis after use of tongue scraper. Emerg Infect Dis 2007; 13(9): 1440-1. [http://dx.doi.org/10.3201/eid1309.070544] [PMID: 18252139]

[40] Beyrich C, Löffler J, Kobsar A, Speer CP, Kneitz S, Eigenthaler M. Infection of human coronary artery endothelial cells by group B streptococcus contributes to dysregulation of apoptosis, hemostasis, and innate immune responses. Mediators Inflamm 2011; 2011 : 971502. [http://dx.doi.org/10.1155/2011/971502] [PMID: 21437210]

[41] Busca A, Saxena M, Kryworuchko M, Kumar A. Anti-apoptotic genes in the survival of monocytic cells during infection. Curr Genomics 2009; 10(5): 306-17.

[http://dx.doi.org/10.2174/138920209788920967] [PMID: 20119528]

\section{(c) 2018 Orrù et al.}

This is an open access article distributed under the terms of the Creative Commons Attribution 4.0 International Public License (CC-BY 4.0), a copy of which is available at: (https://creativecommons.org/licenses/by/4.0/legalcode). This license permits unrestricted use, distribution, and reproduction in any medium, provided the original author and source are credited. 